
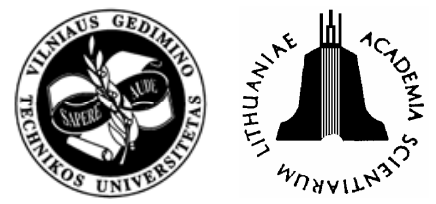

\title{
STATIC BEHAVIOUR ANALYSIS OF MASTS WITH COMBINED GUYS
}

\author{
Donatas Jatulis ${ }^{1}$, Zenonas Kamaitis ${ }^{2}$, Algirdas Juozapaitis ${ }^{3}$ \\ Dept of Bridges and Special Structures, Vilnius Gediminas Technical University, \\ Saulètekio al. 11, LT-10223 Vilnius, Lithuania \\ E-mail:1 jatulis@hotmail.com; ${ }^{2}$ zenonas.kamaitis@ts.vtu.lt, ${ }^{3} a l g @$ st.vtu.lt \\ Received 26 Jan 2007; accepted 30 March 2007
}

\begin{abstract}
The purpose of this study was to develop a new type of guyed mast that incorporates a complex guy cable system with a particular focus on the effect of static loading on the response mast behaviour. The intension of such solution is to increase a number of elastic supports for the mast shaft that will impact on its stability under loading. The static analysis of a one-level guyed mast has been undertaken. The effects of geometrical and physical design parameters on the displacements of the mast were determined. The analysis is illustrated with two-guyed masts: the bending moments and lateral displacements were determined for a typical guyed mast and guyed mast with combined guys.
\end{abstract}

Keywords: guyed mast, combined guys, static loading, geometrical and physical parameters, behaviour modelling.

\section{Introduction}

Guyed masts are special structures widely used for wireless broadcasting and communications industries. The need for taller and more reliable antenna supporting structures is increasing. There are many different setups and configurations of guyed masts designated for particular applications. Usually, a guyed mast consists of a vertical tall mast laterally supported at several levels along its height by sets of inclined pre-tensioned guys spaced at equal angles around the mast and attached to discrete foundations.

The structural analysis of a guyed mast is complex, because of non-linear behaviour of structural system and the random nature of the loads. The choice of initial tension and the non-linear behaviour of the guys can have a very great effect on the deflections as well as dynamic behaviour of a whole structure. For a guyed mast wind and ice are the major loads. Simultaneous wind and ice loads have been blamed for several catastrophic failures of guyed towers in the past $[1,2]$.

Intensive theoretical and experimental research is carried out in the analysis and design of modern tall guyed masts. Fundamental works can be mentioned [eg, $1,3]$ with data for design, analysis and construction of guyed mast with many references on this subject. Windinduced vibration is the critical factor for the safety of guyed masts. Many dynamic models have been proposed in literature, although any of the well-known theories are complex. Several simpler methods based on approximations are proposed [2, 4-8]. In design practice the dynamic response is sometimes neglected. The static wind load, for example, is multiplied by a gust and amplification factors resulting in a higher equivalent static load [4]. As can be seen, design of these structures is not simple.
On the other hand, the capabilities of suspension systems have not yet been sufficiently investigated and exploited and there are vast possibilities for innovative solutions. To increase stability of mast structures and to control vibrations, special measures are sometimes taken. Between them a mast shaft of pre-stressed truss system or guy systems consisting of series of guys with horizontal elements [9], special dampers [10], and star mounts [11] can be mentioned. The solution of suspension system with main and secondary guys to increase a number of elastic supports for the mast shaft has been proposed by the authors of the present paper [12].

In this study a behaviour of guyed mast with combined guys was undertaken to compare static response predictions for a proposed type of guyed masts. The effects of different geometrical and physical design parameters on the lateral displacements of the mast were investigated. Finally, the paper is illustrated with a numerical simulation and comparison of typical and proposed guyed masts.

\section{Description of structure}

The proposed guyed mast structure consists of a vertical mast-column, main and secondary guys (Fig 1). The central mast can be constructed using solid, circular or open steel lattice typically square or of triangular crosssection; however, the first two types need more complicated connection details. The mast is normally guyed in three or four directions, eg, at $120^{\circ}$ or $90^{\circ}$ angles in the plan. The main guys are propped by two additional secondary guys each with half the cross-sectional area to increase the number of intermediate elastic supports and to reduce the effective buckling lengths of the mast. The standard cables are used for main and secondary guys. 

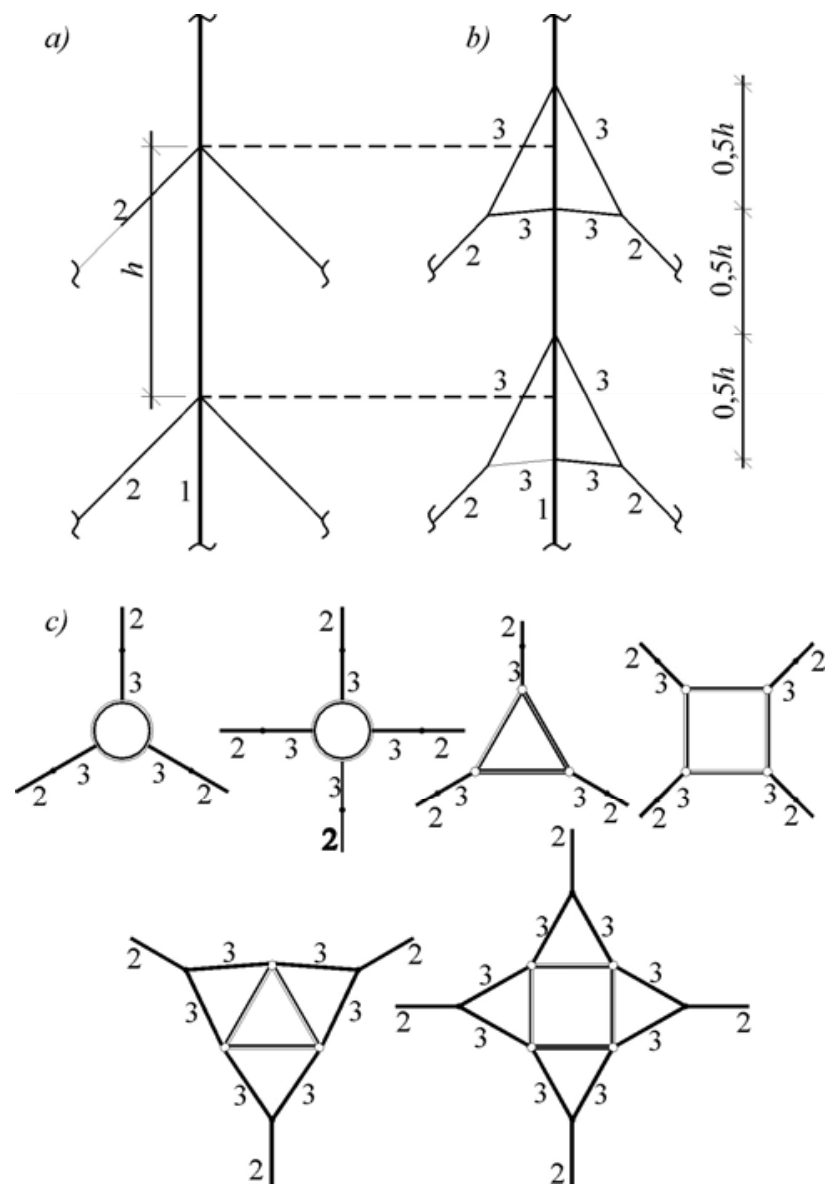

Fig 1. Guyed mast: a - typical system; b - system with combined guys; $\mathrm{c}$ - cross-sections: 1 - central mast; 2 main guy; 3 - additional secondary guy

The number of secondary guys depends of crosssection shape of the mast-column. It is intended to use for each main guy two secondary guy cables situated in vertical plane (eg, in the case of solid mast) and two or four secondary guys, if a mast is latticed (Fig 1, c). The secondary guys are attached to the main guy by special connectors assuring invariable length of the secondary guys. The latter are attached to the vertical mast by the same connectors as in the case of standard guyed masts.

\section{FE modelling of displacements}

The structural analysis of a guyed mast is complex. A difficult problem in the analysis concerns the guy cables. The behaviour of the structure is function of the geometrical and physical design parameters. Such parameters are:

- length of the main cable's chord $(L)$;

- initial length of the main cable in the unloaded status $\left(L_{u}\right)$;

- horizontal projection of secondary guys $\left(l_{x}\right)$;

- angle of inclination of the main cable's chord line $(\alpha)$;

- distance between attachment points of secondary cables $\left(h_{i}\right)$;
- portions between the imaginary point of intersection of main cable axis and mast-column axis and attachment points of secondary cables $\left(h_{a}\right.$ and $\left.h_{b}\right)$;

- initial cable tension $\left(\sigma_{0}\right)$ and cable stiffness $\left(E A_{c a b}\right)$;

- mass and flexural stiffness of the mast $\left(E I_{m}\right)$.

The geometrical parameters of the guyed mast are shown in Fig 2, a.

In order to determine the influence of main design parameters mentioned above on the behaviour of guyed mast, the numerical analysis of guyed mast using commercial program Robot Millennium was performed.

Consider the vertical segment of the guyed mast between two consecutive groups of cables supported laterally by a single guy and loaded with two concentrated forces $F_{1}$ and $F_{2}$ at the anchoring nodes of each secondary guy (Fig 2, b). The mast segment is assumed hinged at two edges at the level of guy supports when translation of supports is prevented. The behaviour of mast segment was determined by modelling the mast as beam-column element and guys as cable element. The cross-sections of main and secondary cables are identical with $E A_{c a b}=12 \mathrm{MN}$. Bending stiffness of the mast $E I_{m}=73,4 \mathrm{MNm}^{2}$. Young's modulus of cables $E=150 \mathrm{GPa}$ and that of the mast column $E=210 \mathrm{GPa}$. Poisson's ratio $v=0,3$. It is also assumed that $h_{i-1}=h_{i}=h_{i+1}=30 \mathrm{~m}$. The sum of two concentrated forces $F_{1}+F_{2}=24 \mathrm{kN}$.

The geometric non-linear static analysis is performed. Horizontal forces were applied in increments and the equations were solved by Newton-Raphson iteration.

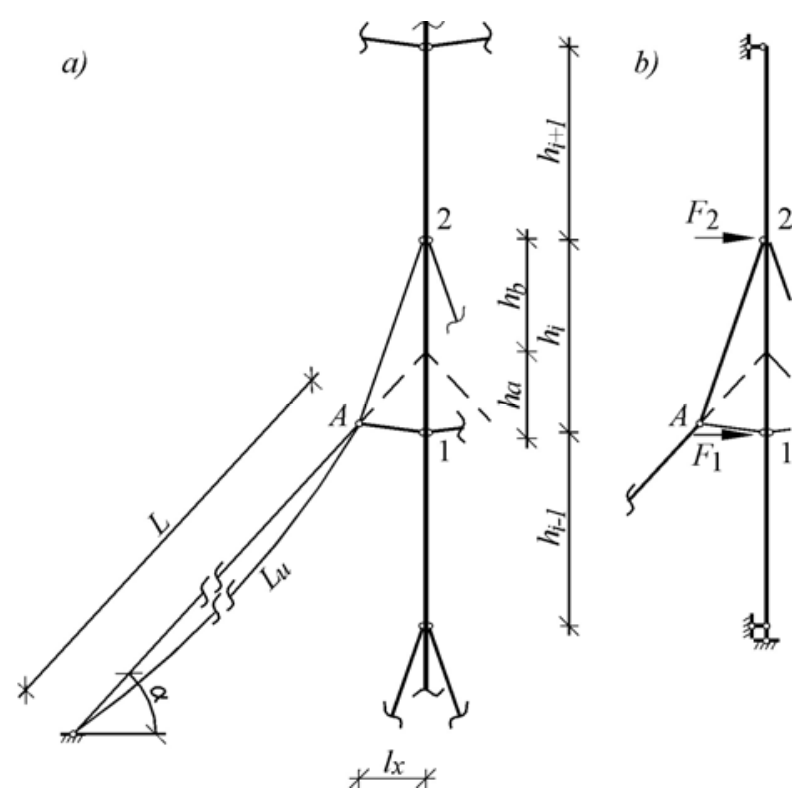

Fig 2. Intermediate segment of the guyed mast, including the combined guy: a - geometrical parameters; b scheme of loading

The analysis model described above was used to undertake a parametric evaluation of lateral displacements. Parameters investigated included: three levels of $h_{i} / l_{x}$, four levels of initial cable tension, three different angles of inclination of the main cables, symmetrical and unsymmetrical loading, and two levels of mast stiffness. 
Due to forces applied (Fig 2, b) the anchoring nods of each secondary guy are free to displace laterally. It is evident that the main factor influencing geometrical parameters of combined guys is the point of intersection of main and secondary guys (point A in Fig 2). Statically equilibrium and cinematic displacements of the system will depend on the imaginary point of intersection of main cable axis and mast-column axis. This apparent line divides the mast length $h_{i}$ into two portions $h_{a}$ and $h_{b}$.

The non-dimensional lateral displacements $u_{i} / h_{i}$ were defined at each point where the secondary guys are connected to the mast. Because of a large number of parameters investigated, the results to variation of lateral displacements could be plotted in many ways. Given below is a summary of the most relevant findings in which the relationship between non-dimensional lateral displacements $u_{i} / h_{i}$ at each point, where the secondary guys are connected to the mast and sector's ratio $h_{a} / h_{b}$ was used. Displacements are summarised in Fig 3.

Typical example of variation of displacements $\left(u_{i} / h_{i}\right)$ with the ratio $h_{a} / h_{b}$ are plotted in Fig 3, a for different levels of $h_{i} / l_{x}\left(\alpha=45^{\circ} ; L_{u} / L=1 ; F_{1}=F_{2}\right)$. It can be observed that an increase in the ratio $h_{a} / h_{b}$ leads to a slight increase in displacements of anchoring node 1 and to a substantial decrease in displacements of node 2 for any values of $h_{i} / l_{x}$. This increase is relatively more important for node 2 than that for node 1 . It is also observed that the ratio $h_{i} / l_{x}$ has little influence on displacements, if $h_{a} / h_{b}=$ $2-4$. For values of $h_{a} / h_{b}>4$, the effect of unstable displacements is observed.

Fig 3, b illustrates the variation of displacements at different values of angle $\alpha$ and Fig 3, c - at different levels of pre-tensioning $\sigma_{0}$ of cables $\left(h_{i} / l_{x}=4 ; F_{1}=F_{2}\right)$. The displacements were found to be a function of the cable tension force. It is generally observed that the higher the value of the angle $\alpha$, ie the higher is the tension stresses and strains in the guy cables, the more important the lateral displacements of the nodes. Variation in $L_{u} / L$ from 0,998 to 1,01 corresponds to pre-tensioning of cables $\sigma_{0}$ from 270 to $6,4 \mathrm{MPa}$. For a given angle $\alpha=45^{\circ}$, the displacements is shown to increase with decreasing cable pre-tensioning force (Fig 3, c).

The influence of symmetrical and unsymmetrical loading, that is the case of wind gust effect, is shown in Fig $3, \mathrm{~d}\left(\alpha=45^{0} ; L_{\mathrm{u}} / L=1 ; h_{i} / l_{x}=4\right)$. As expected, the lateral displacement of an anchoring node is directly proportional to applied load on this node, ie, unsymmetrical loading leads to increase of displacements of a more loaded node.

A strong correlation is observed between the mast's lateral displacements and its bending stiffness (Fig 3, e). Here, an increase in mast's stiffness ratio $K=\frac{E I_{m}}{F h_{i}{ }^{2}}$ induces a significant decrease of displacements in both nodes $\left(L_{u} / L=1 ; F_{1}=F_{2}\right)$. For example, an increase in mast sectional rigidity of 1,8 times decreases the cinematic displacements of up to 4 times.

Considering the displacement curves presented in the figure above, it can also be observed that for all parameters analysed the displacements of both nodes are approximately equal to each other in the region of $h_{a} / h_{b}=0,8-1,3$.

As can be seen from the foregoing analysis, in the modelling and design of guyed masts with combined guys, suitable design parameters should be selected. Based on Fig 3 analysis data, some important recommendations can be drowned. The ratio $\frac{h_{a}}{h_{b}}$ has to be kept in the range of $0,8 \div 1,3$, where the displacements of both nodes are approximately equal. The recommended ratio of mast's segment length $h_{i}$ to horizontal projection of additional cables $l_{x}$, ie $\frac{h_{i}}{l_{x}}$ is of $2 \div 4$, where stable values of displacements are observed. The rational pretensioning of guy cables is obtained at $\frac{L_{u}}{L}=1,000 \div 1,002$. These recommendations can be used as the first approximation for guyed mast design.

\section{Comparison with typical mast}

For the comparative parametric studies, two similar guyed masts with a fixed foot are considered (Fig 4). The behaviour of proposed system was compared with that for a typical guyed mast available in reference [13]. Both masts are 186,2 $\mathrm{m}$ height and have identical geometry and material properties with the exception that the proposed mast has additional guy cables. The lattice steel masts have a rectangular cross-section. The main guys are located at 3 levels and arranged at $90^{\circ}$ in plan. All the main guy cables form the same angle with horizontal plane of $45^{\circ}$. Loading included self weight of the mast

Table 1. Details of guyed masts used in the analysis

\begin{tabular}{|c|c|c|c|c|c|c|c|c|}
\hline 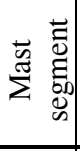 & $\begin{array}{c}\text { Segment } \\
\text { length } \\
l_{k}, \mathrm{~m}\end{array}$ & $\begin{array}{c}\text { Mast bending } \\
\text { stiffness } \\
E I, \mathrm{kN}\end{array}$ & $\begin{array}{l}\text { Lateral load on } \\
\text { column of the } \\
\text { mast, } \mathrm{kN} / \mathrm{m}\end{array}$ & 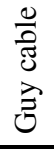 & $\begin{array}{c}\text { Cable tension } \\
\text { stiffness } \\
E A_{c a b}, \mathrm{kN}\end{array}$ & $\begin{array}{l}\text { Guy cable } \\
\text { pretension } \\
\text { force, } \mathrm{kN}\end{array}$ & $\begin{array}{c}\text { Construction lateral } \\
\text { load on the guys } \\
q_{b 0}, \mathrm{kN} / \mathrm{m}\end{array}$ & $\begin{array}{l}\text { Lateral load on the } \\
\text { guys under wind } \\
\text { pressure } q_{b}, \mathrm{kN} / \mathrm{m}\end{array}$ \\
\hline \multirow{2}{*}{$k-1$} & \multirow{2}{*}{49,00} & \multirow{2}{*}{1663776} & \multirow{2}{*}{1,56} & 1 & 172656 & 176,6 & 0,0714 & 0,1108 \\
\hline & & & & 2 & 172656 & 176,6 & 0,0714 & 0,0032 \\
\hline \multirow{2}{*}{$k-2$} & \multirow{2}{*}{47,25} & \multirow{2}{*}{1171314} & \multirow{2}{*}{2,19} & 3 & 172656 & 137,3 & 0,0714 & 0,1130 \\
\hline & & & & 4 & 172656 & 137,3 & 0,0714 & 0,0096 \\
\hline \multirow{2}{*}{$k-3$} & \multirow{2}{*}{74,25} & \multirow[t]{2}{*}{1171314} & \multirow{2}{*}{3,57} & 5 & 269775 & 294,3 & 0,1012 & 0,1746 \\
\hline & & & & 6 & 269775 & 294,3 & 0,1012 & 0,0402 \\
\hline
\end{tabular}


a)

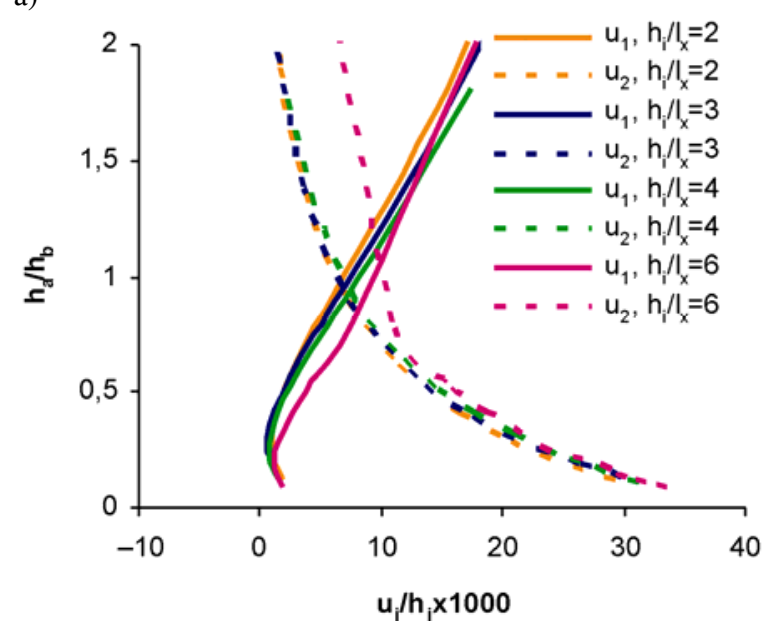

c)

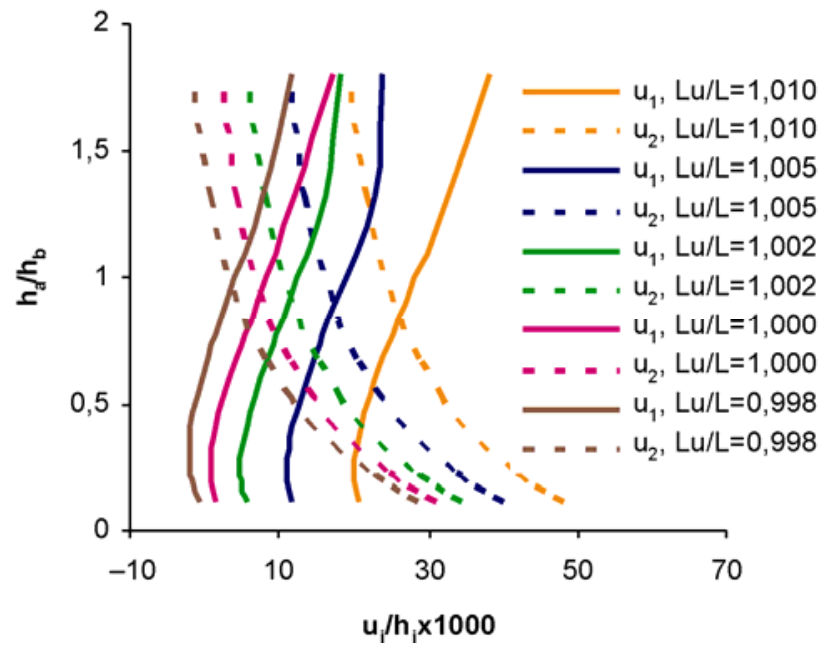

b)

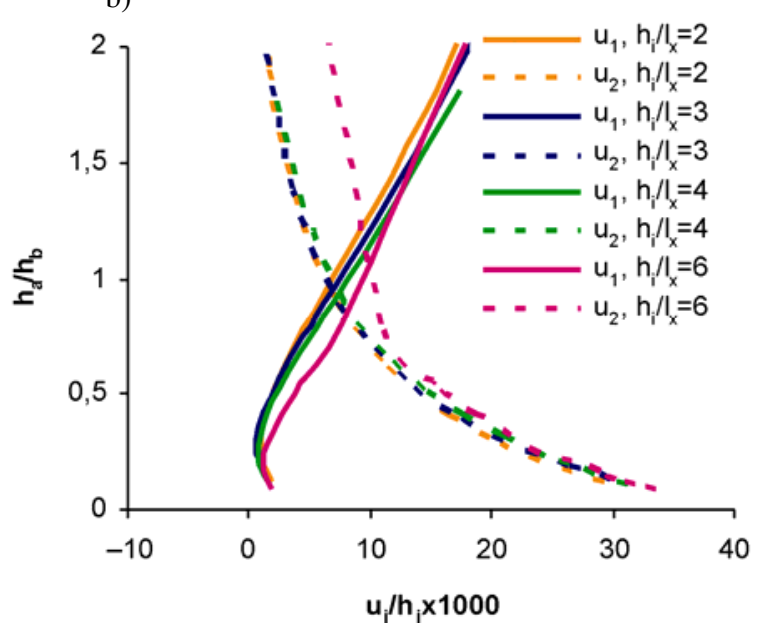

d)

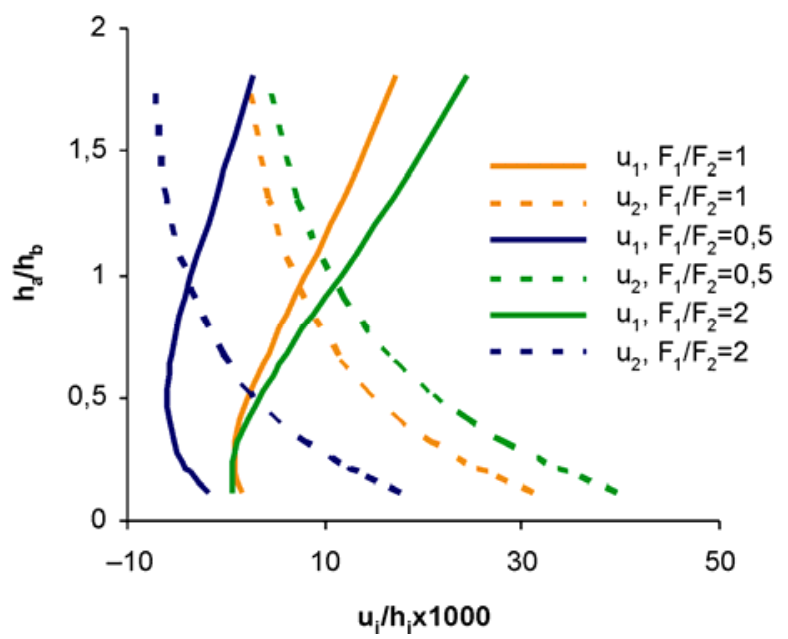

e)

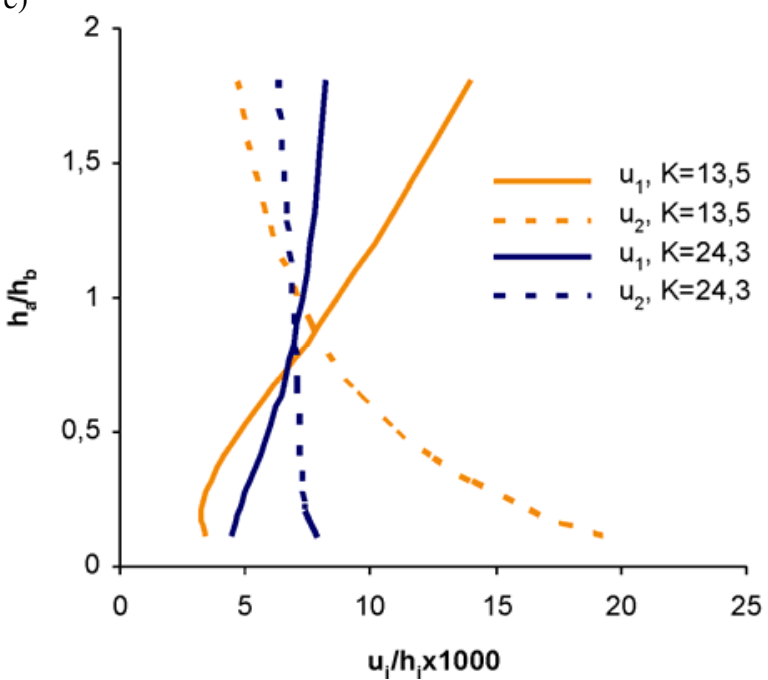

Fig 3. Relations between relative displacements $u_{i} / h_{i}$ of anchoring nods and sectors ratio $h_{a} / h_{b}$ for a segment of vertical mast at different ratio $h_{i} / l_{x}$ (a); angle of inclination of main cable $\alpha$ (b), main cable's length ratio $L_{u} / L$ (c), applied forces ratio $F_{1} / F_{2}(\mathrm{~d})$, and mast stiffness ratio $K(\mathrm{e})$ 
a)

$1-1$

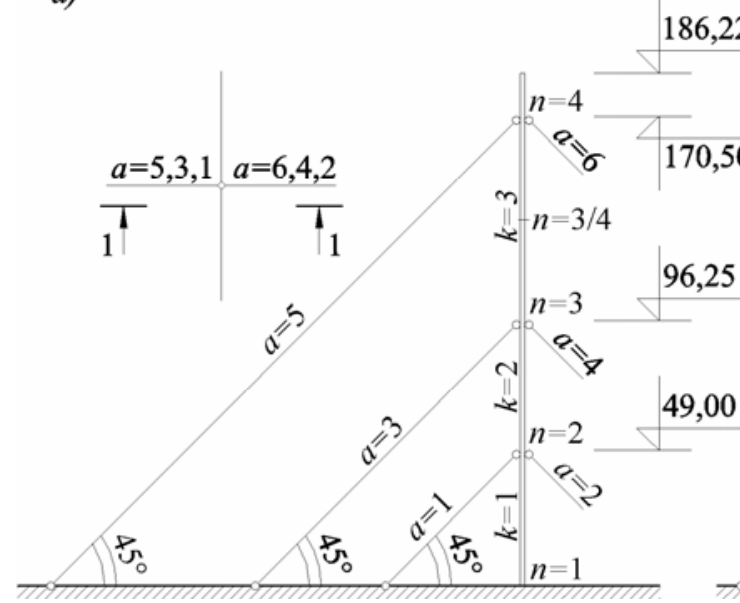

b)

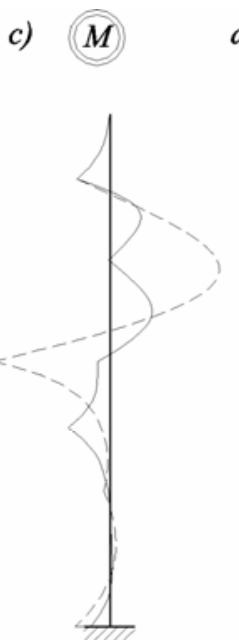

d)

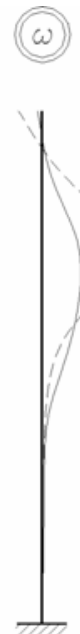

Fig 4. Typical guyed mast (a), guyed mast with combined guys (b), bending moment (c) and horizontal displacement (d) diagrams: ------- typical guyed mast; — mast with combined guys

and static component of the wind load. The dynamic effects of the wind were neglected. Details of guyed masts are presented in Table 1. The numerical analysis was performed using program Robot Millennium.

In Fig 4, c, d and Table 2 a comparison is made between bending moments and horizontal displacements for a typical and new guyed mast. As can be seen the combined guys have significant influence on the bending moments and lateral displacements of the mast. The additional guys enable to increase the number of intermediate elastic supports for the mast shaft and to increase its stiffness that results in smaller deflections of the mast. It is expected that combined guys can reduce the effect of tortional moments in the mast as well as vibration amplitudes due to wind.

Table 2. Comparison of analytical results for two types of guyed masts

\begin{tabular}{|c|c|c|c|c|}
\hline & $\begin{array}{l}\text { Cross- } \\
\text { section }\end{array}$ & $\begin{array}{c}\text { Typical } \\
\text { guyed mast } \\
(a)\end{array}$ & $\begin{array}{l}\text { Guyed mast } \\
\text { with com- } \\
\text { bined guys } \\
\text { (b) }\end{array}$ & $\begin{array}{l}\text { Ratio } \\
\frac{b}{a}\end{array}$ \\
\hline \multirow{4}{*}{$\begin{array}{l}\text { Bending } \\
\text { moments in } \\
\text { the mast, } \\
\mathrm{kNm}\end{array}$} & 1 & 457,2 & 253,8 & 0,555 \\
\hline & 2 & 120,7 & 58,8 & 0,487 \\
\hline & 3 & 1510,0 & 137,5 & 0,091 \\
\hline & 4 & 436,5 & 436,5 & 0,0 \\
\hline \multirow{5}{*}{$\begin{array}{l}\text { Lateral } \\
\text { displace- } \\
\text { ments of the } \\
\text { mast, cm }\end{array}$} & 1 & 0 & 0 & 0,0 \\
\hline & 2 & 1,9 & 1,9 & 0,0 \\
\hline & 3 & 26,5 & 21,5 & 0,811 \\
\hline & $3-4$ & 85,9 & 35,0 & 0,407 \\
\hline & 4 & 11,8 & 8,6 & 0,729 \\
\hline \multirow{6}{*}{$\begin{array}{l}\text { Tension } \\
\text { forces in the } \\
\text { guy cables, } \\
\mathrm{kN}\end{array}$} & 1 & 211,8 & 213,9 & 1,010 \\
\hline & 2 & 145,3 & 138,8 & 0,955 \\
\hline & 3 & 352,4 & 260,9 & 0,740 \\
\hline & 4 & 9,15 & 16,2 & 1,770 \\
\hline & 5 & 422,0 & 488,0 & 1,156 \\
\hline & 6 & 162,0 & 112,1 & 0,692 \\
\hline $\begin{array}{l}\text { Axial force } \\
\text { at the base, } \\
\mathrm{kN}\end{array}$ & 1 & 2104 & 2053 & 0,976 \\
\hline
\end{tabular}

\section{Conclusions}

The guyed mast with a new configuration of cables has been proposed. It consists of 3 main components: tower mast, combined guy cables composed of main and secondary guys, and discrete foundations. The additional secondary guys increase the number of intermediate elastic supports and reduce the effective buckling lengths of the mast.

The numerical analysis of guyed mast's horizontal displacements by varying geometrical and physical parameters using program Robot Millennium was performed. The lateral displacements of the mast were found to be a function mainly of the point position of intersection of main and secondary guys (or the ratio $h_{a} / h_{b}$ ), the asymmetry of applied forces, the cable pretension force, and mast stiffness (Fig 3).

By choosing design parameters the displacements and bending moments of a given mast may be controlled. The recommended rational parameters $\frac{h_{a}}{h_{b}}=0,8 \div 1,3$; $\frac{h_{i}}{l_{x}}=2 \div 4$, and $\frac{L_{u}}{L}=1,000 \div 1,002$ were obtained in this study. This should be of particular interest for guyed masts design.

To verify the validity of combined guys, the comparison is made with an existing solution for a typical guyed mast. The comparison showed that the combined guys result in smaller bending moments and horizontal displacements in the mast. It is expected that combined guys can reduce the effect of torsional moments as well as vibration amplitudes due to wind. Additional research is needed into the prediction of dynamic behaviour of new type structures.

\section{References}

1. MADUGULA, M. K. S (ed). Dynamic response of lattice towers and guyed masts. Committee report, Reston: American Society of Civil Engineers, 2002. 266 p. 
2. GANTES, CH. Preliminary design of guyed towers using axiomatic principles. In Proc of the 11th European Conference of Steel Structures, Athens (Greece), 8-20 May 1995, p. 421-428.

3. SMITH, B. W. Communication structures. Thomas Telford, 2007. $352 \mathrm{p}$.

4. GERSTOFT, P.; DEVENPORT, A. G. A simplified method for dynamic analysis of a guyed mast. Journal of Wind Engineering and Industrial Aerodynamics, 1986, 23(1), p. 487-499.

5. GANTES, CH.; KHOURY, R.; CONNOR, J. J.; POUANGARE, C. Modeling, loading, and preliminary design considerations for tall guyed towers. Computers and Structures, 1993, 49(5), p. 797-805.

6. SPARTING, B. F.; SMITH, B. W.; DEVENPORT, A. G. Simplified dynamic analysis methods for guyed masts in turbulent winds. Bulletin of the International Association for Shell and Spatial Structures, 1996, 37(2), p. 89-106.

7. MESHMESHA, H.; SENNAH, K.; KENNEDY, J. B. Simple method for static and dynamic analyses of guyed towers. Structural Engineering and Mechanics, 2006, 23(6), p. 635-649.
8. JUOZAITIS, J.; PRANEVIČIUS, J.; ŠAPALAS, A. The influence of displacements and oscillations on behavior of masts. Journal of Civil Engineering and Management, 2002, 8(1), p. 57-60.

9. VOJEVODIN, A. Prestressed guyed radio-masts. Moscow: Radio i sviaz, 1981. 176 p. (in Russian).

10. SMITH, R. C.; KOSS, L. L. Ball and oil dampers for mast structures. Journal of Wind Engineering and Industrial Aerodynamics, 1995, 56(2), p. 169-183.

11. KAHLA, N. B. Influence of star mounts on guyed towers. Computers and Structures, 1995, 54(5), p. 989-995.

12. KAMAITIS, Z.; JUOZAPAITIS, A.; JATULIS, D. Masts with combined guys and analysis of their behavior. In Proc of the 8th International Conference "Modern Building Materials, Structures and Techniques", Vilnius, 1922 May, 2004. Selected papers, ed E. K. Zavadskas, P. Vainiūnas and F. M. Mazzolani, Vilnius: Technika, p. 502-507.

13. PERELMUTER, A. V. Fundamental theory of static analysis of tension structures. Moscow: Strojizdat, 1969. 190 p. (in Russian).

\section{STIEBŲ, TURINČIŲ MIŠRIĄSIAS ATOTAMPAS, STATINĖ ELGSENOS ANALIZĖ}

\section{Jatulis, Z. Kamaitis, A. Juozapaitis}

\section{Santrauka}

Aptariama originali plieninio stiebo konstrukcinè sandara, kurioje vietoje iprastinių vientisų atotampų taikomos mišriosios, turinčios atšakas, atotampos, sutelkiant demesị i statinès apkrovos itaką stiebo elgsenai. Pagrindinis šio sprendinio privalumas - paslankiujų atramų kiekio kamiene padidinimas, kas tiesiogiai daro įtaką stiebo stabilumui esant apkrovai. Statinès analizès metu buvo išnagrinèta pagrindinių komponuojamujų geometrinių ir fizinių parametrų įtaka vieno atotampų lygio kamieno ruožo paslankiujų atramų poslinkiams. Atlikta ịprasto ir naujo tipo stiebo poslinkių ir įražų lyginamoji analizè.

Reikšminiai žodžiai: stiebas, mišriosios atotampos, statinė apkrova, geometriniai ir fiziniai parametrai, elgsenos modeliavimas.

Donatas JATULIS. PhD student at the Dept of Bridges and Special Structures, Vilnius Gediminas Technical University (VGTU), Lithuania. MSc (2002) from the Vilnius Gediminas Technical University. Research interests: development of guyed-mast structures, non-linear analysis of the cables, guyed masts.

Zenonas KAMAITIS. Dr Habil, Prof Emeritus at the Dept of Bridges and Special Structures, Vilnius Gediminas Technical University (VGTU), Lithuania. Member of IABSE since 1999. Author and co-author of more than 150 publications, including 6 books. Research interests: special structures and bridges, structural analysis, materials, durability, monitoring, and refurbishment.

Algirdas JUOZAPAITIS. Assoc Prof at the Dept of Bridges and Special Structures, Vilnius Gediminas Technical University (VGTU), Lithuania. PhD at VGTU. Research interests: steel bridges and special steel structures, optimal shape determining structures, geometrical non-linear analysis of structures. 